\title{
Representasi Tubuh Ideal Perempuan dalam Iklan WRP Versi Limited
}

\section{Edition}

\author{
Sabila Putri Annafi (Penulis Korespondensi) \\ Program Studi Ilmu Komunikasi, Universitas Muhammadiyah Yogyakarta, Indonesia \\ Sabilaputrian14@gmail.com \\ Latifah Nurul Azizah \\ Program Studi Ilmu Komunikasi, Universitas Muhammadiyah Yogyakarta, Indonesia \\ Latifahnurul02@gmail.com \\ Diserahkan: 09 Mei 2020; Direvisi: 09 Oktober 2020; Diterima: 10 Oktober 2020
}

\begin{abstract}
This study aims to describe how the ideal female body is represented in the Limited Edition version of the WRP ad. The ideal body of women is often represented differently by the media, which means that this meaning is different from the natural meaning of the ideal female body. So that society agrees and a perception of the meaning of the ideal female body is formed according to what the media represents. This research uses descriptive qualitative methods with critical studies, or operationally uses operational methods to analyze objects. The result of this research is the Limited Edition of WRP's advertisement tries to build a message that the ideal woman must be a woman who has a body with language without excess fat so that self-confidence appears. Conversely, women who have excess fat are considered not ideal.

Keywords: Ideal, Perception, Representation, Body
\end{abstract}

\begin{abstract}
Abstrak
Penelitian ini bertujuan untuk memaparkan bagaimana tubuh ideal perempuan direpresentasikan dalam iklan WRP versi Limited Edition. Tubuh ideal perempuan serigkali direpresentasikan dengan makna berbeda oleh media, yang mana makna tersebut berbeda dengan makna alami tentang tubuh ideal perempuan. Sehingga masyarakat sepakat dan terbentuklah persepsi akan makna tubuh ideal perempuan sesuai dengan apa yang media representasikan. Penelitian ini menggunakan metode deskriptif kualitatif dengan kajian kritis, atau secara operasional menggunakan metode semiotika untuk menganalisis obyek penelitian. Hasil dari penelitian ini adalah iklan WRP versi Limited Edition berusaha membangun pesan bahwa perempuan ideal haruslah perempuan yang memiliki tubuh langsing tanpa lemak berlebih sehingga muncul rasa percaya diri. Sebaliknya perempuan yang memiliki lemak berlebih dianggap tidak ideal.
\end{abstract}

Kata Kunci: Ideal, Persepsi, Representasi, Tubuh

\section{PENDAHULUAN}

Sebagai salah satu bagian dari cara untuk mempromosikan produk, iklan menjadi salah satu alternatif yang paling banyak dicari oleh sebagian masyarakat untuk menarik minat konsumen. Definisi iklan menurut Dewan Periklanan Indonesia merupakan pesan komunikasi pemasaran atau komunikasi publik tentang sesuatu produk yang disampaikan melalui suatu media, dibiayai oleh pemrakarsa yang dikenal, serta ditujukan kepada sebagian atau seluruh masyarakat (Zakky, 2019). Saat ini, tidak sedikit iklan yang dinilai sudah melanggar etika periklanan diantaranya iklan-iklan yang mempresentasikan tentang tubuh ideal.

Adapun salah satu iklan yang mempresentasikan tentang tubuh ideal yaitu iklan WRP versi Limited Edition. Dalam iklan tersebut terlihat sekali representasi tubuh ideal perempuan yang dinilai menjadi standar kesempurnaan yaitu perempuan yang memiliki tubuh tinggi, langsing, dan memiliki kulit yang putih bersih. WRP sendiri merupakan susu pengganti makan yang diklaim untuk menurunkan berat 
badan dengan kalori yang terkontrol, tinggi protein, dan tinggi kalsium dengan rasa yang lebih enak serta alami.

Apabila dicermati dengan seksama, iklan WRP menampilkan pemeran perempuan yang tidak bebas dalam menggunakan pakaian selain warna hitam. Penggunaan pakaian berwarna hitam dimaksudkan untuk mengindari penampilan tubuh gemuk. Dalam iklan tersebut, ditampilkan suatu adegan seorang perempuan sebelum meminum WRP yang terlihat berlemak ketika memakai pakaian ketat selain warna hitam. Hal tersebut merepresentasikan bahwa tubuh ideal yang menjadi standar perempuan adalah tubuh yang ditampilkan setelah mengonsumsi WRP versi Limited Edition. Secara tidak langsung, hal tersebut dapat menyinggung perempuan yang tidak mengonsumsi produk WRP dan mendorong perasaan tidak nyaman.

Penelitian ini penting untuk dilakukan karena dinilai turut menciptakan realitas bahwa tubuh ideal perempuan adalah tinggi, langsing, dan berkulit putih. Di luar kriteria tersebut, perempuan dinilai belum memiliki tubuh yang ideal. Tujuan dari penelitian ini adalah untuk mengetahui representasi tubuh ideal perempuan dalam iklan WRP versi Limited Edition. Selain itu, tujuan dari penelitian ini adalah untuk mengetahui bagaimana representasi tubuh ideal perempuan dalam iklan WRP versi Limited Edition.

\section{KAJIAN PUSTAKA}

Penelitian terdahulu yang dilakukan oleh Melly Marlianti dan Ade Suryani (2012) menghasilkan dua temuan, yang pertama adalah tubuh perempuan bukanlah tubuh yang bersifat alami juga kodrati yang diberikan tuhan. Dalam hal ini, tubuh perempuan adalah tubuh yang sudah diinterpretasi dan dirubah secara sosial sesuai dengan image yang ingin dibangun oleh media yang bersangkutan. Majalah Femina turut serta memberi pemahaman yang bergantung pada nilai interpretasi tentang konsep representasi tubuh juga kecantikan. Tubuh perempuan dijadikan sebagai objek sesuatu yang bisa diubah juga dibentuk sesuai kemauan mereka. Hal tersebut akan tercapai apabila perempuan menggunakan beberapa perawatan tubuh.

Kedua, tubuh perempuan dijadikan sebagai objek sasaran kegiatan konsumtif. Tubuh perempuan segaja diinterpretasi dan dibangun lewat media, lalu media memberi rekomendasi sekaligus solusi bagaimana mengatasi permasalahan-permasalahan tubuh perempuan dan kecantikan dengan memperlihatkan produk perawatan tubuh, pusat perawatan tubuh, dengan harga yang bervariatif. Majalah Femina melalui salah satu artikelnya memotivasi perempuan agar tetap terlihat cantik sekaligus menarik sesuai dengan apa yang mereka representasikan dalam rubrik kecantikan. Dari sinilah, perempuan yang membaca majalah Femina akan tertarik untuk menjadi konsumen dari produk yang majalah Femina rekomendasikan. Berbeda dengan penelitian yang diangkat oleh Melly Marlianti dan Ade Suryani yang mengangkat tentang representasi tubuh perempuan dalam majalah Femina, penelitian ini mengangkat tentang representasi tubuh ideal perempuan dalam iklan WRP versi Limited Edition.

\section{KERANGKA TEORI}

REPRESENTASI

Berbicara mengenai representasi, definisi representasi sendiri menurut Chris Barker adalah langkah dalam mengkonstruksikan dunia sosial tentang penyajian makna kepada masyarakat dan oleh masyarakat dalam pemaknaan yang berbeda. Dalam kajian kebudayaan (cultural studies), focus kajian akan mengarah pada individu dalam proses pemaknaan sebuah arti masalah sosial/fakta sosial terhadap representasi (pemaknaan setiap individu-individu) (Winarni, 2010). Jen Webb dalam bukunya menjelaskan bahwa representasi berdiri bukan lebih dari sekedar untuk masalah sederhana, tetapi 
representasi juga lebih produktif dari apa yang kita ketahui dan bagaimana cara kita mengetahui, yang artinya representasi bersifat konstitutif. Lebih singkatnya representasi adalah bagaimana kita mengalami dan mengkomunikasikan diri kita dan dunia yang kita tempati, bagaimana kita mengenal diri kita sendiri, dan bagaimana kita berurusan dengan orang lain.

Selain pengertian di atas, representasi juga dipahami sebagai kegiatan membuat realitas namun bukan realitas yang sesungguhnya. Konsep ini digunakan untuk menggambarkan ekspresi hubungan antar teks iklan (media) dengan realitas. Representasi secara literal bermakna "penghadiran kembali" atas sesuatu yang terjadi sebelumnya, melakukan mediasi, dan memainkannya kembali untuk menggambarkan hubungan antara teks media dengan realitas. Representasi pun dapat berarti penggambaran dunia sosial dengan cara yang tidak lengkap dan sempit (Grossberg dalam Winarni, 2010).

\section{SENSUALITAS}

Sensualitas pada perempuan yang ideal merupakan aspek yang sering kali dieksploitasi oleh para pelaku media untuk menarik minat audiens. Menurut Ida dan Surya (2002) definisi konsep sensualitas tidak dirumuskan dengan rumusan yang jelas. Namun, asumsi yang telah berkembang di masyarakat secara umum menyatakan bahwa sensualitas merujuk pada aksi yang sengaja dipertontonkan untuk mengundang imajinasi seksual bagi yang mengonsumsinya. Pakaian minim dan terbuka merupakan beberapa contoh yang membentuk konsep sensualitas itu sendiri. Konsep sensualitas ini berhubungan erat dengan kemampuan panca indera manusia dalam menangkap objek tertentu. Biasanya objek yang sifatnya visuallah yang paling kuat membentuk konsep sensualitas (Fitriani, 2014).

Media menekankan arti sensualitas perempuan lewat berbagai macam adegan seperti mempertegas sifat kewanitaannya secara biologis yakni cantik, memikat, dan pelayan laki-laki. Seperti yang sekarang terjadi, sebuah iklan tidak hanya menampilkan gambar sebuah produk. Di dalamnya sering kali terdapat kalimat rayuan dan erotika dengan menggunakan semiotasi atau tanda tertentu seperti senyuman, lirikan mata, lenggak lenggok tubuh, dan lainnya.

\section{SEMIOTIKA}

Semiotika berasal dari bahasa Yunani yakni semieon yang berarti tanda. Semiotika diperkenalkan oleh Ferdinand De Saussure (1857-1913). Semiotika berangkat dari kajian tentang tanda (sign) yang terdiri dari dua aspek, yaitu penanda (signifier), dan petanda (signified). Penanda bisa dipahami sebagai bentuk atau wujud fisik, seperti audio, gambar, visual, dan sejenisnya. Sedangkan petanda ialah konsep atau arti dari apa yang ditandai. Hubungan antara keduanya bersifat "diada-adakan" (arbitrary), yakni tidak ada hubungan bersifat alamiah antara penanda dan petanda. Meski demikian, hubungan yang bersifat "diada-adakan" tersebut terikat oleh konvensi atau struktur.

Pemikiran Ferdinand De Saussure kemudian dikembangkan oleh Roland Barthes dengan memberi telaah dalam interaksi antara teks dengan pengalaman personal dan kultural penggunanya. Interaksi antara konvensi dalam teks dengan konvensi yang dialami dan diharapkan oleh penggunanya dikenal dengan tatanan penandaan (order of signification). Gagasan Roland Barthes tersebut mencakup primary signification atau denotasi (makna sebenarnya sesuai kamus) dan secondary signification atau konotasi (makna ganda yang lahir dari pengalaman kultural dan personal). Makna konotasi inilah yang kemudian berkembang menjadi mitos. Dalam penelitian ini, penulis berusaha melakukan analisis semiotika, mulai dari primary signification sampai secondary signification pada iklan WRP versi Limited Edition. 


\begin{tabular}{c|c}
\hline $\begin{array}{c}\text { Signifier } \\
\text { (Penanda) }\end{array}$ & $\begin{array}{c}\text { Signified } \\
\text { (Petanda) }\end{array}$ \\
\hline \multicolumn{2}{c}{$\begin{array}{c}\text { Denotatif Sign } \\
\text { (Tanda Denotatif) }\end{array}$} \\
$\begin{array}{c}\text { Connotatif Signifier } \\
\text { (Penanda Konotatif) }\end{array}$ \\
\multicolumn{2}{c}{$\begin{array}{c}\text { Connotatif Signified } \\
\text { (Petanda Konotatif) }\end{array}$} \\
\hline \multicolumn{2}{c}{ (Tanda Konotatif) }
\end{tabular}

Gambar 1. Pemaknaan tanda dalam semiotika Roland Barthes (Sobur, 2004)

\section{METODE PENELITIAN}

Penelitian ini merupakan penelitian deskriptif kualitatif dengan paradigma kritis. Secara lebih operasional, penelitian ini menggunakan metode semiotika untuk menganalisis objek penelitian. Objek penelitian dalam penelitian ini adalah iklan WRP versi Limited Edition tahun 2014. Iklan tersebut berbentuk video dan berdurasi tayang 30 detik. Objek yang digunakan dalam penelitian ini dianalisis dengan menggunakan analisis semiotika Roland Barthes yang mengembangkan pemikiran dari Ferdinand De Saussure.

\section{HASIL DAN PEMBAHASAN}

\section{REPRESENTASI TUBUH IDEAL PEREMPUAN}

Kecantikan perempuan yang memiliki tubuh ideal dalam iklan sering kali di representasikan dengan perempuan yang memiliki kulit yang putih bersih dan mulus. Seperti yang dikutip kembali oleh Rina Wahyu Winarni, Bush menemukan kesamaan kriteria kecantikan pada 37 kebudayaan yang membuat laki-laki tertarik pada perempuan, yaitu bibir penuh, kulit putih, bersih dan halus, mata jernih, rambut berkilau, dan kulit kencang. Kriteria ini secara universal dicari untuk menggambarkan kecantikan. Kesamaan kecantikan perempuan tentang warna kulit juga diungkap oleh Mulyana (2005) yang mengungkapkan bahwa kulit putih dianggap berstatus lebih tinggi dari pada kulit hitam, konon didambakan $87 \%$ wanita Indonesia menurut sebuah iklan kosmetik di televisi swasta (Winarni, 2010).

Hal tersebut semakin terbukti dengan orang-orang yang mulai mengubah cara berpikir bahwa perempuan yang memiliki kulit putih lebih cantik dan menarik dibandingkan dengan perempuan yang memiliki warna kulit sawo matang ataupun kuning langsat. Seiring perkembangan zaman, makin banyak iklan yang merepresentasikan mengenai standar kecantikan perempuan yang memiliki tubuh ideal ialah perempuan berkulit putih. Seperti halnya dalam iklan citra body lotion yang dulunya menjadikan warna kuning langsat sebagai standar kecantikan pada kulit perempuan. Seiring dengan berjalannya waktu, saat ini citra body lotion menjadikan warna kulit putih menjadi standar kecantikan pada kulit perempuan. Hal tersebut dinilai lebih menarik dibandingkan dengan warna kulit yang lain.

Selain iklan citra body lotion, masih banyak iklan lainnya yang menggunakan representasi perempuan bertubuh ideal diantaranya adalah iklan susu dewasa WRP versi Limited Edition. Dalam penayangan iklan WRP versi Limited Edition ditunjukkan dengan jelas bahwa perempuan pemeran iklan tersebut memiliki kulit putih bersih dan mulus. Hal tersebut dinilai menjadi daya tarik tersendiri agar konsumen yang menonton tayangan iklan tersebut memiliki keinginan membeli produk yang diiklankan.

Berkaitan dengan standar kecantikan, kecantikan sendiri dilahirkan oleh politik yang memberikan nilai kecantikan sesuai standar fisik yang dipaksakan oleh budaya (Wolf, 2002). Media saat ini pun memiliki peran dalam membangun nilai kecantikan tersebut Media saat ini mempresentasikan perempuan cantik dengan beberapa ciri-ciri fisik diantaranya adalah memiliki rambut hitam legam. Faktanya, hal tersebut banyak mempengaruhi masyarakat sehingga masyarakat mematok ukuran rambut 
ideal yakni rambut yang memiliki warna hitam juga panjang. Sebaliknya, saat ini perempuan yang tidak memiliki rambut berwarna selain hitam dan tidak panjang masuk dalam kategorisasi tidak ideal. Hal tersebut juga dapat dilihat dalam iklan-iklan shampoo di televisi yang mana selalu menampilkan model perempuan dengan rambut halus, hitam, dan panjang. Tidak hanya iklan shampoo, bahkan saat ini, iklan-iklan atau bahkan film juga menampilkan hal yang sama. Begitupun dalam iklan susu WRP versi Limited Edition. Iklan tersebut dengan jelas memperlihatkan model iklan yang memiliki rambut hitam legam dan panjang.

\section{REPRESENTASI SENSUALITAS TUBUH PEREMPUAN DALAM IKLAN WRP VERSI LIMITED EDITION}

Mayoritas media iklan cenderung menggunakan perempuan sebagai objek dengan konsep yang seringkali tanpa disadari menampilkan sensualitas tubuh perempuan untuk ditayangkan dan dijadikan media promosi suatu produk. Iklan WRP versi Limited Edition yang berdurasi sekitar kurang lebih 31 detik sendiri menggambarkan bagaimana tubuh ideal perempuan haruslah tinggi, putih, langsing, dan berambut panjang.

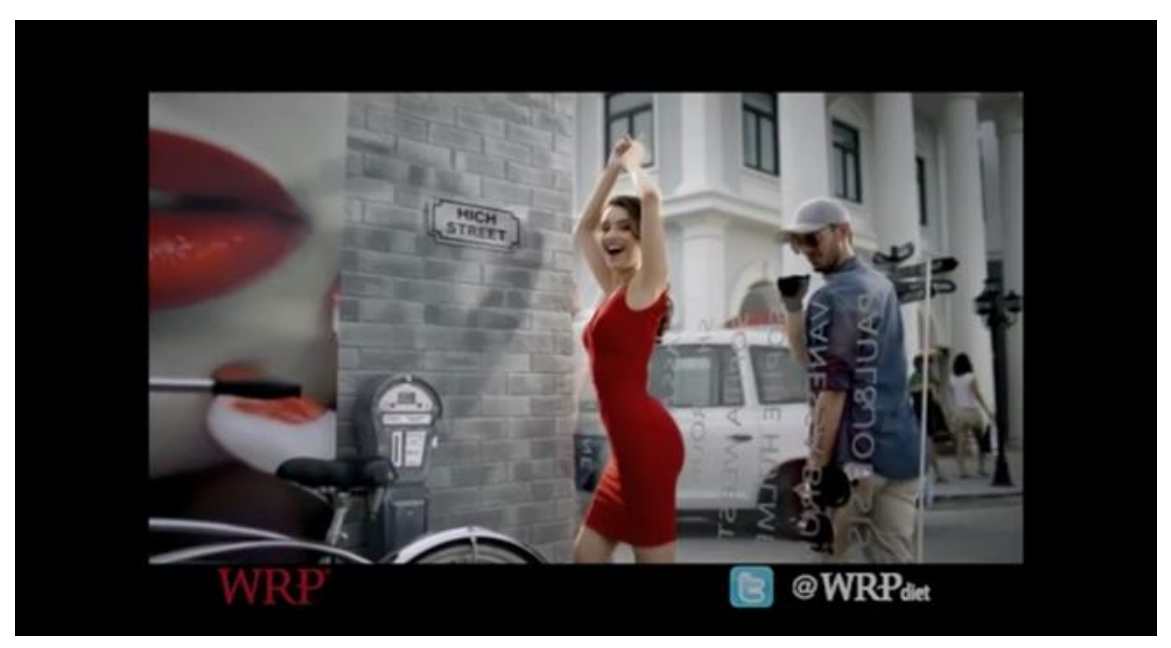

Gambar 2. Scene perempuan berjalan menyerongkan tubuhnya detik ke 0:27 (Youtube, 2014)

Iklan WRP versi Limited Edition dianggap menampilkan sensualitas tubuh perempuan seperti pada detik ke 0:27 gambar 2. Dalam cuplikan iklan tersebut ditampilkan bahwa perempuan memakai mini dress berwarna merah berjalan dengan menyerongkan tubuhnya di sela-sela ruang antara tembok dengan kaca yang tepat berada di sudut belokan antara tembok dan jalan. Perempuan tersebut menampilkan bagaimana kondisi tubuh perempuan yang ideal setelah mengonsumsi WRP versi Limited Edition. Namun demikian, yang menjadi masalah bukan di bagian tersebut, melainkan di bagian saat menyerongkan badan, angle kamera mengambil gambar dengan memperlihatkan seolah-olah pria yang sedang membawa kaca melihat tubuh bagian bawah perempuan. Gambar tersebut secara tidak langsung ingin menunjukkan bahwa tubuh ideal yang dimaksud salah satunya tercermin dari tubuh bagian bawah yang menonjol.

Dalam hal ini, tubuh perempuan dianggap sebagai "the other". Artinya, tubuh perempuan dinilai berbeda dengan tubuh laki-laki. Perempuan memiliki bagian-bagian tubuh tertentu yang lebih menonjol ketimbang laki-laki, seperti payudara, pinggul, dan bokong. Hal ini lah yang kemudian membuat tubuh perempuan menjadi sasaran eksploitasi. Bagian-bagian tubuhnya yang dianggap berbeda dengan laki-laki 
tersebut, dianggap menjual. Tak heran, tubuh perempuan sering kali dijadikan objek visual oleh pelaku media, terutama pengiklan (King, 2004).

Media yang notabene sangat lekat dengan kehidupan kita selalu menggambarkan perempuan sesuai dengan opini yang pihak media buat tentang perempuan, baik tentang tubuh ideal perempuan maupun sifat-sifatnya. Sehingga, penggambaran oleh media secara tidak sadar telah menjadi patokan masyarakat dalam mempresentasikan perempuan. Salah satu jalan media dalam mempresentasikan perempuan adalah melalui iklan. Iklan tidak selalu menceritakan tentang bagaimana produk dapat segera dibeli konsumen. Akan tetapi, beberapa di antaranya juga ingin menyampaikan citra kuat mengenai apa dan bagaimana langkah yang diambil produk dan memberitahukan arti dalam iklan tersebut (Nurfazrin \& Raturahmi, 2016).

Iklan WRP versi Limited Edition turut serta berperan dalam mempresentasikan tubuh ideal yang diinginkan perempuan masa kini. Dalam iklan tersebut perempuan yang memiliki tubuh sedikit berlemak di bagian perut digambarkan sebagai perempuan yang tubuhnya tidak ideal, sedangkan perempuan yang langsing digambarkan sebagai perempuan dengan tubuh yang ideal. Hal ini dapat dilihat dari model perempuan yang diceritakan tidak percaya diri karena mempunyai tubuh berlemak di bagian perut. Setelah meminum susu WRP, perempuan tersebut menjadi langsing dan percaya diri. Iklan tersebut secara tidak langsung memiliki dampak buruk yakni membuat perempuan yang berbeda dari apa yang dipresentasikan sebagai tubuh ideal menjadi insecure atau tidak percaya diri dengan tubuh yang mereka punya.

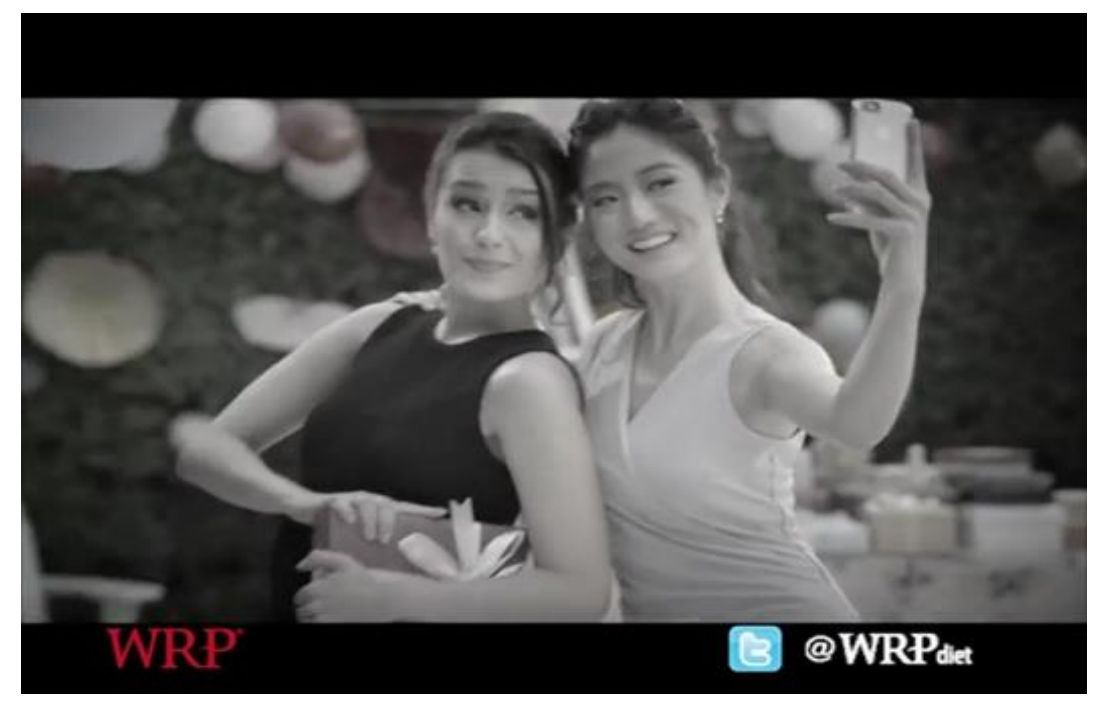

Gambar 3. Perempuan yang sedang tidak percaya diri ketika ber-selfie. (Youtube, 2014) 


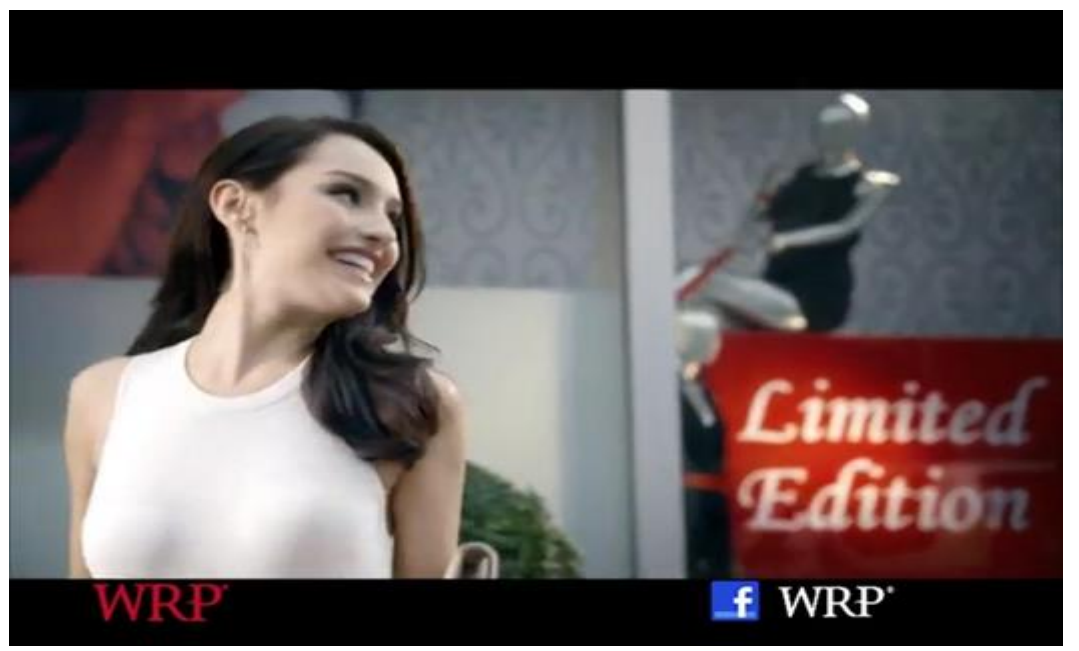

Gambar 4. Perempuan yang percaya diri memakai pakaian warna putih (Youtube, 2014).

Dari gambar di atas dapat kita ketahui bahwa dalam iklan WRP versi Limited Edition ini, perempuan dalam scene 0:10 yang memiliki lemak berlebih di bagian perut digambarkan tidak bisa memakai pakaian selain pakaian berwarna hitam, dikarenakan lemak di perutnya akan terlihat saat memakai pakaian berwarna lainnya. Perempuan yang memiliki lemak di bagian perut tersebut dalam iklan WRP versi Limited Edition ini juga digambarkan beraut wajah kurang senang dan terkesan tertekan. Sedangkan perempuan dalam scene 0:05 yang memiliki tubuh langsing karena telah meminum susu WRP digambarkan beraut wajah senang dan bahagia. Selain itu, ia juga sudah berani memakai pakaian berwarna selain warna hitam, yakni putih dan merah.

Iklan WRP versi Limited Edition di atas tidak hanya menampilkan bagaimana standar ideal tubuh perempuan, di balik itu terdapat beberapa makna tersembunyi dalam iklan tersebut. Contohnya seperti gambar dalam kemasan WRP versi Limited Edition di bawah ini,

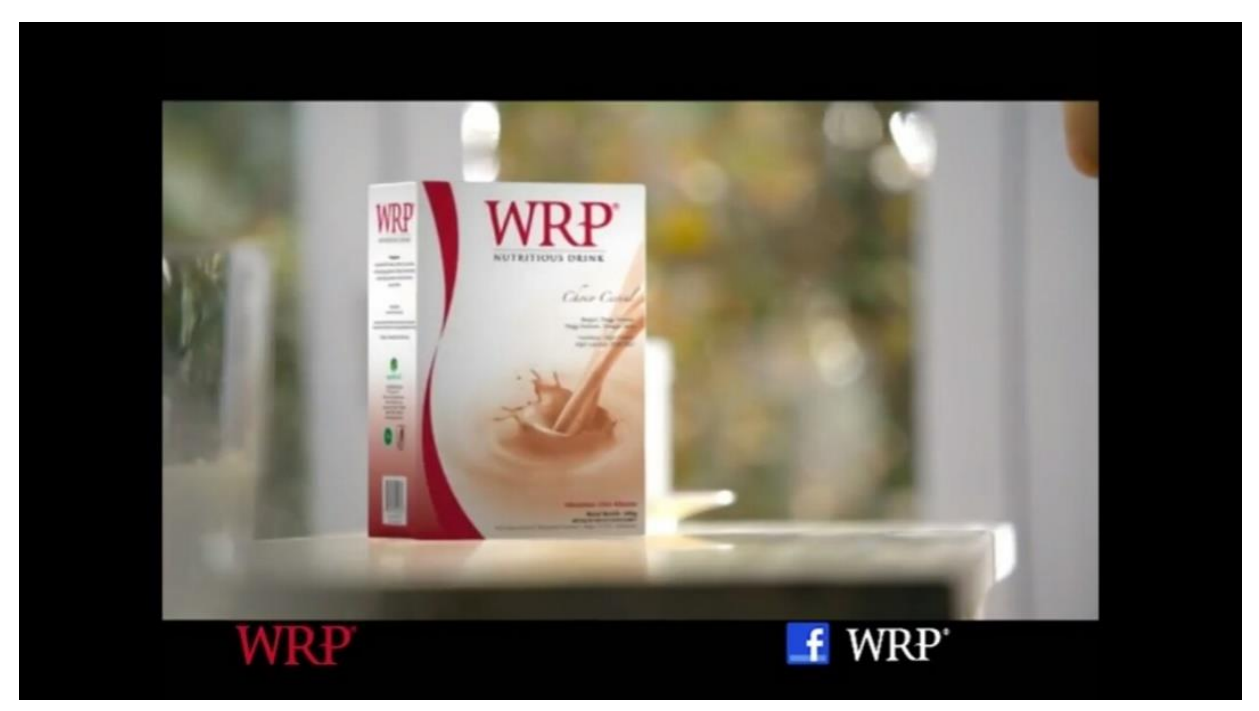

Gambar 5. Kemasan susu WRP versi Limited Edition (Youtube, 2014).

Dalam kemasan tersebut terdapat garis berwarna merah melengkung yang artinya menunjukkan penggambaran sebagai lekuk tubuh seorang perempuan yang seharusnya melengkung pada tempat yang tepat yaitu di bagian pinggul agar dapat dikatakan sebagai perempuan yang memiliki tubuh ideal. 
Dalam penggambarannya, warna merah yang terdapat pada kemasan WRP dapat diartikan dengan berani. Secara umum, dapat dikatakan bahwa perempuan yang telah memiliki tubuh seperti penggambaran garis berwarna merah melengkung tersebut dapat lebih berani mengekspresikan diri mereka karena memiliki tubuh yang ideal. Kemudian terdapat gambar 1.3 yang menggambarkan perempuan akan mengonsumsi WRP versi Limited Edition.

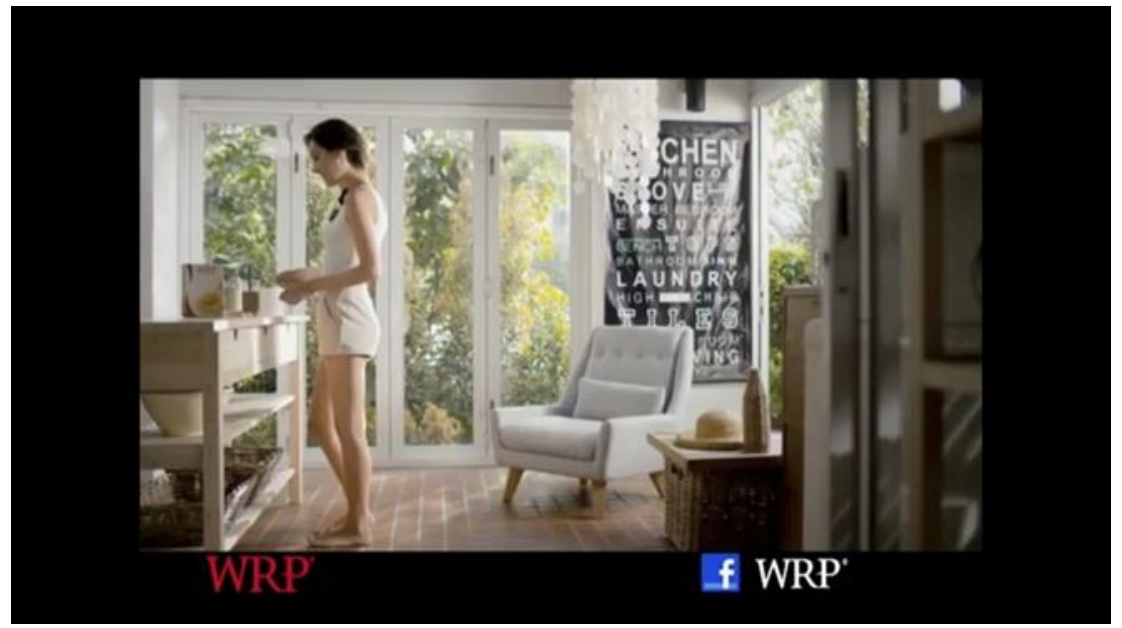

Gambar 6. Perempuan akan mengonsumsi WRP versi Limited Edition (Youtube, 2014).

Gambar di atas dapat dimaknai sebagai sebuah janji dalam iklan, apabila kita mengonsumsi produk tersebut maka kita akan memiliki tubuh ideal yang dinilai menarik dan membuat kita lebih percaya diri dengan menggunakan pakaian seperti itu.

\section{KESIMPULAN}

Dari hasil analisis yang telah dilakukan, dapat disimpulkan bahwa penulis telah memberikan gambaran mengenai bagaimana representasi tubuh ideal perempuan yang terdapat pada iklan WRP versi Limited Edition. Pelaku produksi iklan menggunakan perempuan sebagai objek yang dijadikan umpan agar menarik perhatian para konsumen untuk membeli produk yang ditawarkan. Dalam iklan tersebut terlihat sangat jelas bahwa perempuan dituntut untuk tampil sempurna di depan kamera dengan memperlihatkan bentuk tubuhnya. Dengan ditayangkannya iklan tersebut di media massa, secara tidak langsung hal tersebut membuat para perempuan beranggapan bahwa standar tubuh ideal bagi para perempuan sesungguhnya seperti apa yang ditayangkan dalam iklan, di luar semua itu dianggap sebagai sesuatu yang buruk. Perempuan dalam iklan tersebut secara dominan telah dijadikan objek daya tarik untuk menarik perhatian penonton. Tidak sedikit penayangan iklan juga menampilkan model perempuan dengan menunjukkan sensualitasnya.

\section{PERSANTUNAN}

Terima kasih kepada Dr. Fajar Junaedi yang telah membimbing proses penelitian yang kami lakukan dalam mata kuliah Kajian Kritis Iklan di Program Studi Ilmu Komunikasi UMY, selama satu semester genap tahun akademik 2019/2020 yang menghasilkan luaran berupa artikel ini.

\section{REFERENSI}

Aprilia, D. R. (2013). Iklan dan Budaya Popular: Pembentukan Identitas Ideologis Kecantikan

Perempuan oleh Iklan. Jurnal Ilmu Komunikasi, 1(2), 41-65. 
Fitriana, R. (2014). Perempuan dan Sensualitas: Bentuk Komodifikasi Tubuh Perempuan melalui Body Images yang Dikonstruksikan didalam Iklan AXE. Diakses dari http://www.journal.unair.ac.id/filerPDF/comm13ef248188full.pdf

King, A. (2004). The Prisoner of Gender: Foucault and the Disciplining of the Female Body. Journal of International Women's Studies, 5(2), 29-39.

Mulyana, D. (2005). Ilmu Komunikasi Suatu Pengantar. Bandung: Remaja Rosdakarya

Suryani, N. M. (2012). Representasi Tubuh Perempuan dalam Rubrik Kecantikan dalam Majalah Femina Edisi Mei 2011. Jurnal Komunikologi, 9(2), 67-73.

Webb, J. (2009). Understanding Representation. London: SAGE Publication Ltd.

Winarni, R. W. (2010). Representasi Kecantikan Perempuan dalam Iklan. Deiksis, 2(2), 134-152.

Wolf, N. (2002). The beauty Myth. London: Vintage Books. 